\title{
E-Trust and Post-Purchase Experience on Repurchase Intention through Customer Satisfaction: Study on Instagram
} Account @ Jastipmlg

\author{
Amara Naafiarsha ${ }^{1}$, Harianto Respati ${ }^{2}$, Achmad Fridiansjah ${ }^{3}$ \\ ${ }^{1}$ Student in Magister of Management, University of Merdeka Malang, Indonesia \\ ${ }^{2,3}$ Faculty of Economics and Business, University of Merdeka Malang, Indonesia
}

\section{ABSTRACT}

This study examines four variables between e-trust, post-purchase experience, customer satisfaction, and repurchase intention. The objective is to analyze and explain the effect of e-trust and post-purchase experience on repurchase intention by testing customer satisfaction as an intervening variable. The object of research is personal shoppers also known as Jasa Titip through Instagram, namely the @jastipmlg. 100 respondents in this study are followers and customers who make repurchases. The analysis technique uses descriptive analysis and linear regression to confirm the structural equation model that is built. The quantitative approach was chosen to explain the influence of the research variables. The results of this study found that e-trust and post-purchase experience affect repurchase intention through customer satisfaction. This study examines four variables between e-trust, post-purchase experience, customer satisfaction, and repurchase intention. The objective is to analyze and explain the effect of e-trust and post-purchase experience on repurchase intention by testing customer satisfaction as an intervening variable. The object of research is personal shoppers also known as Jasa Titip through Instagram, namely the @jastipmlg. 100 respondents in this study are followers and customers who make repurchases. The analysis technique uses descriptive analysis and linear regression to confirm the structural equation model that is built. The quantitative approach was chosen to explain the influence of the research variables. The results of this study found that e-trust and post-purchase experience affect repurchase intention through customer satisfaction.

\section{KEYWORDS: Repurchase Intention, Customer Satisfaction, e-Trust, Post-purchase intention, online purchase}

\section{INTRODUCTION}

Customer retention is often seen as a means of gaining competitive advantage (Tsai \& Huang, 2007). However, only about $1 \%$ of online visitors return to make repeat purchases (Gupta \& Hee-Woong, 2007). Therefore, it is important to study online customer repurchase behavior (Qureshi et al., 2009).

The rise of online shopping consumption has made the emergence of resellers increase. One of the types of Resellers in Indonesia is a personal shopper also known as "Jasa Titip" using the platform Instagram. Currently, Instagram is not only a place to upload photos but also a means for doing digital marketing activities. According to Muslicha and Irwansyah (2020), social media platforms have developed as a form of global communication and bridge the relationship between people and products.

Back to the research object, personal shoper or "Jasa Titip" or called Jastip is a business that is carried by one who will be traveling to outside the city or outside the country to buy the product that is desired by consumers but with an extra price (Hapsari \& Saudi, 2018)

According to Hapsari \& Saudi (2018), this business is quite attractive because sellers do not need a large amount of capital and can be used as a part-time business. The success of Jastip depends on consumer trust. If consumers trust the seller, https://ijbassnet.com/ they likely to get loyal customers so that sellers have the opportunity to get repeat orders. According to Pleessis (2010), consumers are satisfied with the performance of shopping online has influence positively the repurchase intention. It shows that trust is an important variable in repurchase decisions.

Furthermore, researchers also realized that the online shopping process was not completed finish with payment. Shopping online is closely related to the packaging of goods, delivery up to get into consumers, where the activity is called post-purchase logistics. Ho and $\mathrm{Wu}$ (1999) found that logistics specifications are the most important factors in determining customer satisfaction in electronic business. Referring to previous research by Cao et al. (2017), found that postpurchase shipping and tracking impact on customer satisfaction that they do in China and Taiwan. So, the researchers concluded that to find out customer satisfaction in online shopping, it is very important to include the postpurchase experience that customers feel.

Event post-purchase includes aid products, service customers, shipping, tracking, repair, and return of goods ( Zoltners et al., 2004; Chauhan and Rambabu, 2017). In addition to affecting customer satisfaction, previous research has also proven that post-purchase experience influences repurchase intention. Experience post-purchase or posthttp://dx.doi.org/10.33642/ijbass.v6n8p7 


\section{CCenter for Promoting Education and Research (CPER) USA $\underline{w w w . c p e r n e t . o r g}$}

purchase experience contributed very big in developing the intention of repeat order (Park et al, 2012).

From that, the researchers want to know the latest variables that influence repurchase intention, especially against this phenomenon of shopping online with Instagram as a personal shopper (jasa titip). Researchers obtain that there is a relationship between the variables of e- trust, post-purchase experience, and customer satisfaction that became the potential to have the effect that significant to the repurchase intention. Thus, the study is trying to look for relationships e-trust and post-purchase experience that is given by @ jastipmlg through the platform of social media Instagram to Repurchase Intention with considering a variable Customer Satisfaction as variable intervening.

\section{THEORETICAL BACKGROUND}

\subsection{E-Trust}

Trust refers to someone's belief that other people are not going to act as opportunistic by taking advantage of situations (Beldad, De Jong, and Steehouder, 2010; Koller, 1988; Qureshi et al., 2009). Trust in an online site is known as e- trust. According to Kim et al. in Anindea (2016), e-Trust is defined as the beginning of the basis of relationship formation and maintenance between customers and sellers online. In general, customers online expect a high level of quality web sites, the quality of information, and the quality service of the website and the seller (Kim et al., 2004). The indicators of etrust in this study trust in the web and trust in sellers. To measure trust in the website the researcher uses website reputation and the size of the website company. Meanwhile, the seller's reputation and the size of the seller's company are used to measure the indicators of trust in the seller.

According to Shiau \& Luo (2012) trust is an important variable of satisfaction, trust can create a favorable feeling that customer needs can be met by the website and the seller. So in this study, the trust variable is e-trust, which includes trust in websites and trust in sellers that affect customer satisfaction.

\subsection{Post-purchase Experience}

Post-purchase Experience is an experience that begins after the purchase is made and ends with the consumption or return of the product (Kumar \& Ayush, 2017). The experience of post-purchase contributes very largely in developing the intention of repeat order (Park et al., 2012) experience after doing decision purchases via e-commerce or shopping online is more specific to the post-purchase logistics.
On the other hand, from the results of previous studies by $\mathrm{Cao}$ et al. (2018) confirm that post-purchase logistics services such as shipping, tracking, and returns are useful in predicting customer satisfaction for online shoppers. So, the researchers found that post-purchase experience affects customer satisfaction. Post-purchase Experience includes aid products, customer services, shipping, tracking, repair, and return of goods (Zoltners et al., 2004; Chauhan and Rambabu, 2017). In this research, indicator activities of post-purchase include Customer Service, Shipping, Tracking, and Return.

\subsection{Customer Satisfaction}

Customer satisfaction is a feeling of pleasure or disappointment for someone who comes from a comparison between his impression of the product compared to his expectations (Samuel \& Foedjiawati., 2005). Customer satisfaction has been found to have a direct and positive effect on customer purchase intentions and repetitive behavior (eg, Tsiotsou, 2006; Chiou and Pan, 2009). In the context of online media, users seem to decide whether to continue using media based on their satisfaction with previous user experiences (e.g., Hu, Kettinger, \& Poston, 2015; Venkatesh, Thong, Chan, Hu, \& Brown, 2011).

According to the definition of Anderson and Srinivasan (2003) satisfaction can be defined as the satisfaction of consumers concerning the experience of purchase before the web site retail. Similar to the idea that Lin \& Wang (2006) said that satisfaction is the evaluation of postpurchase customer and respond effectively to experience the purchase as a whole. Some attribute of satisfaction of consumers who associated with this research is an attribute that is associated with the product, the attributes are associated with the service, and attributes are associated with the purchase.

\subsection{Repurchase Intention}

Repurchase Intention is the attitude of a positive consumer to the retailer that will result in the purchase of a recurring (repeat buying behavior). Zhou et.al. (2009) and Kim et al, (2012), the intention of buying back may mean consumers are interested to do purchase by using shopping online, shopping online consumers will be reviewed back in the future and consumers keen to recommend shopping online because they also use shopping online. In past research, Wen et al. (2011) shown that satisfaction is positively related to repurchase intention. Pee et al (2018) prove similarly that dissatisfied consumers ultimately reduce repurchase intentions. 


\section{(C) Center for Promoting Education and Research (CPER) USAwww.cpernet.org}

\section{METHODOLOGY}

\subsection{Research Framework}

The research framework is as shown in Figure 3.1

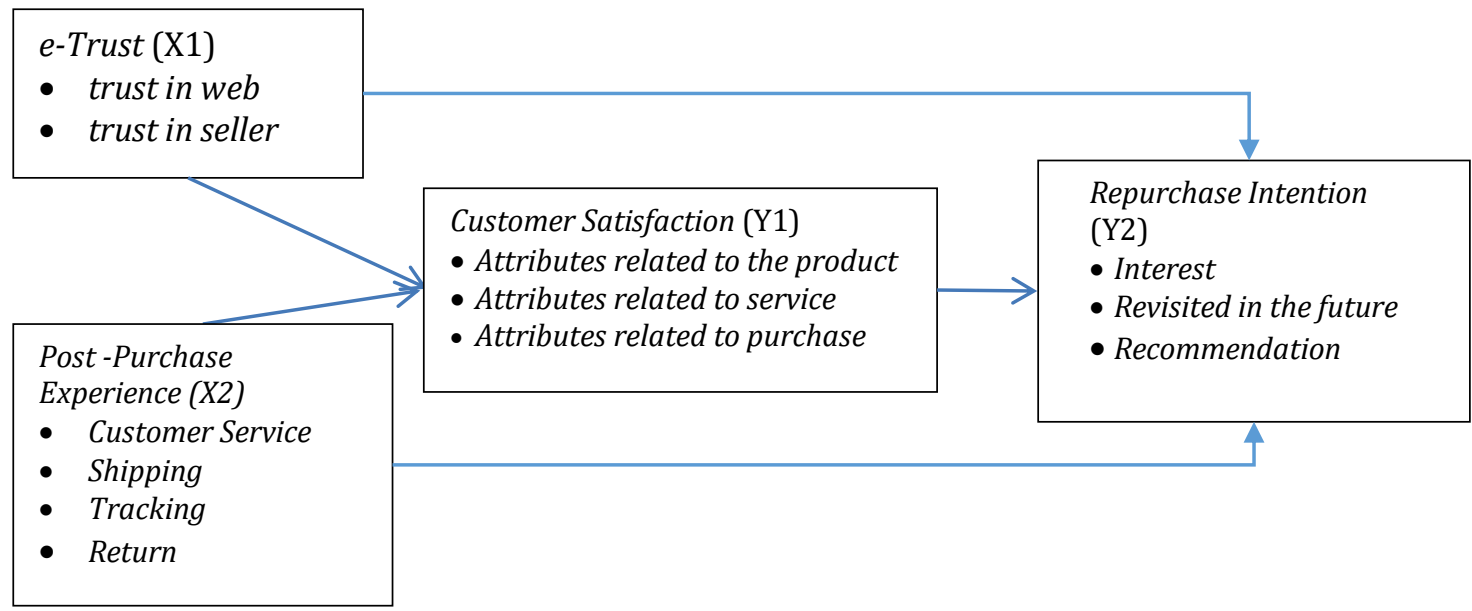

\subsection{Hypotheses}

The purpose of this study is to investigate the effects of e-trust and post-purchase intention on repurchase intention through customer satisfaction. After reviewing the relevant literature, the hypotheses for the study are constructed as follows:

H1: e-trust and post-purchase experience are significant to customer satisfaction

H2: e-trust and post-purchase experience are significant to repurchase intention

H3: Customer satisfaction is significant to repurchase intention H4: e-Trust and post-purchase experience are significant to repurchase intention through customer satisfaction

\subsection{Methodology}

\subsubsection{Subject and Procedure}

We utilized the survey questionnaire and repurchase intention as the product being studied. The population in this studywas all @jastipmlg Instagram followers were on June 13, 2020, there were 10,214 followers. The Slovin formula is used to determine the sample by considering the error rate of $10 \%$, to obtain a sample size of 100 respondents. Respondents were identified as suitable candidates for participation in this study if they met the eligibility criteria that they follow account@jastipmlg and had purchased at least one time. Anonymous questionnaires were given to 100 participants.

\subsubsection{Instrumentation}

The questionnaire was designed based on a five-point Likert scale and was adopted from previous studies with high levels of reliability (Cronbach's $\alpha$ above 0.6). The questionnaire consisted of two parts. Part I gathered demographic data. Part II consisted of multiple questions relating to variables and indicators. The structure of the variables, indicators, and the number of research instruments is presented in table 3.1 below.

\section{Table 3.1 Instrument Research}

\begin{tabular}{|c|c|}
\hline Variable and Indicator & Amount of Instrument \\
\hline e-Trust $\left(\mathrm{X}_{1}\right)$ & 3 \\
\hline Trust in web $\left(\mathrm{X}_{1,1}\right)$ & 3 \\
\hline Trust in seller $\left(\mathrm{X}_{1,2}\right)$ & \\
\hline Post Purchase Experience $\left(\mathrm{X}_{2}\right)$ & 3 \\
\hline Customer Service $\left(\mathrm{X}_{2,1}\right)$ & 3 \\
\hline Shipping $\left(\mathrm{X}_{2,2}\right)$ & 3 \\
\hline Tracking $\left(\mathrm{X}_{2,3}\right)$ & 2 \\
\hline Return $\left(\mathrm{X}_{2,4}\right)$ & \\
\hline Customer Satisfaction $\left(\mathrm{Y}_{1}\right)$ & 5 \\
\hline Attributes related to the product $\left(\mathrm{Y}_{1.1}\right)$ & 5 \\
\hline Attributes related to service( $\left.\mathrm{Y}_{1.2}\right)$ & 5 \\
\hline Attribute related to purchase $\left(\mathrm{Y}_{1.3}\right)$ & \\
\hline Repurchase Intention $\left(\mathrm{Y}_{2}\right)$ & 1 \\
\hline Interest $\left(\mathrm{Y}_{2.1}\right)$ & 2 \\
\hline Revisited in the future $\left(\mathrm{Y}_{2.2}\right)$ & 2 \\
\hline Recommendation $\left(\mathrm{Y}_{2.3}\right)$ & 28 \\
\hline \multicolumn{1}{|c|}{ Total } & \\
\hline
\end{tabular}




\section{CCenter for Promoting Education and Research (CPER) USA $\underline{w w w . c p e r n e t . o r g}$}

\subsubsection{Validity and Reliability of Instrument}

Analysis of data processing using the SPSS program. There are four research variables with 12 indicators and 28 instrument items. The results of the validity and reliability testing for 28 items proved to be valid, as evidenced by the probability of each instrument not exceeding the 5\% error rate, meaning that the respondent understood the meaning of the measurements contained in the questionnaire (See Appendix). The results of the research instrument reliability test showed a good level of reliability as evidenced by the Cronbach Alpha value resulting in value above the Standard Cronbach Alpha (0.6). So, all variables were said to be reliable. In addition to Factor Analysis and Reliability Analysis, the data collected from the instruments were analyzed using the SPSS software for descriptive statistics, and Regression Analysis.

\section{ANALYSIS AND RESULT}

\subsection{Description of Respondent}

Instagram account @jastipmlg is a business account that provides personal shopper for consumers in Malang and outside Malang. This personal shoper means a shopping service for fashion goods in the ZARA, Uniqlo, Pull and Bear, Stradivarius, Berskha, and other brands in malls in Surabaya. Researchers measure the services of @ jastipmlg about e-trust, post-purchase experience, and customer satisfaction as intervening variables on repurchase intention.

The data collected were 100 questionnaires. Respondent profiles are presented in Table 4.1.

\section{Table 4.1 Profile Respondent}

\begin{tabular}{|l|r|r|}
\hline \multicolumn{1}{|c|}{ Age } & \multicolumn{1}{|c|}{$\%$} \\
\hline $13-17$ y.o & & 13 \\
\hline $18-24$ y.o & & 45 \\
\hline $25-34$ y.o & & 38 \\
\hline $35-44$ y.o & & 4 \\
\hline Gender & & $\%$ \\
\hline Female & & 100 \\
\hline
\end{tabular}

Most respondents are female, in the range of 18 to 24 years, meaning that respondents at the age often use online shopping applications through the Instagram platform.

\subsection{Result of Descriptive Analysis}

The results of the descriptive analysis for each research variable, indicator, and 66 research instruments are presented in the appendix. The description of respondents' perceptions can be analyzed from the average value generated by the indicators and instrument items. The indicator that best describes the e-trust variable is trust in the web, especially on customer trust in product photos posted by @ jastipmlg. The indicator that best describes the post-purchase experience variable is customer service, especially the ease of finding the admin number. For the satisfaction variable, the indicator that best describes is the attribute related to the product, especially the quality of the product with photos posted @ jastipmlg. On the repurchase intention variable, the indicator that can explain the interest in repurchasing is the recommendation, especially a statement giving a good review of @ jastipmlg.

4.3 Result of Regression Analysis of E- Trust, PostPurchase Experience, Customer Satisfaction, and Repurchase Intention

The regression results summary is shown in Figure 4.1 and Table 4.3. All models were statistically significant ( $p<$ 0.05 ) and a total of two regression equations are reported here. All the regression coefficients were positive indicating that customers had a higher level of repurchase intentions when they trust, had good post-purchase experience and satisfaction with @ jastipmlg.

Figure 4.1

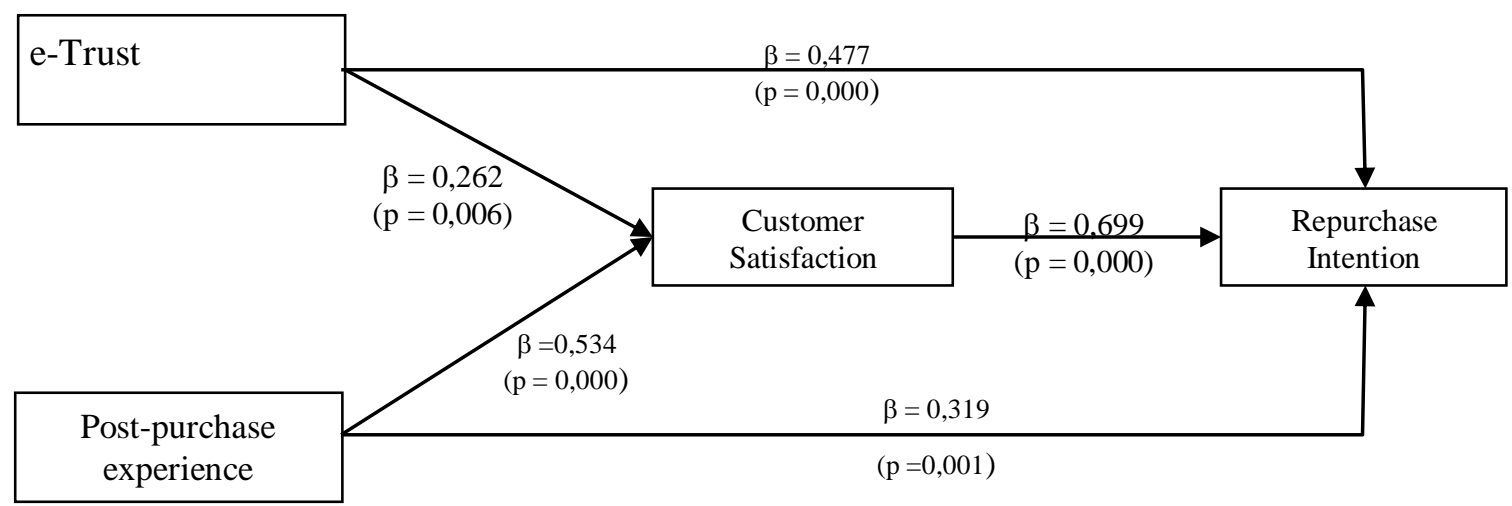




\section{(C) Center for Promoting Education and Research (CPER) USAwww.cpernet.org}

Table 4.3

\begin{tabular}{|c|c|c|c|c|c|c|c|c|}
\hline & & \multicolumn{3}{|c|}{ Variable } & \multicolumn{3}{|c|}{ Coefficients } & \multirow[t]{2}{*}{ result } \\
\hline Independent & & Mediation & & Dependent & direct & indirect & Total & \\
\hline$e$-Trust (X1) & $\rightarrow$ & $\begin{array}{c}\text { Customer } \\
\text { Satisfaction } \\
\text { (Y1) }\end{array}$ & & - & 0,262 & & 0,283 & $\begin{array}{c}\text { H1 } \\
\text { Significant }\end{array}$ \\
\hline $\begin{array}{l}\text { Post-purchase } \\
\text { Experience (X2) }\end{array}$ & $\rightarrow$ & $\begin{array}{c}\text { Customer } \\
\text { Satisfaction } \\
\text { (Y1) }\end{array}$ & & - & 0,534 & & 0,326 & $\begin{array}{c}\text { H1 } \\
\text { Significant }\end{array}$ \\
\hline$e$-Trust(X1) & $\rightarrow$ & & & $\begin{array}{l}\text { Repurchase } \\
\text { Intention } \\
(Y 2)\end{array}$ & 0,477 & & 0,543 & $\begin{array}{c}\mathrm{H} 2 \\
\text { Significant }\end{array}$ \\
\hline $\begin{array}{l}\text { Post-purchase } \\
\text { Experience (X2) }\end{array}$ & $\rightarrow$ & & & $\begin{array}{l}\text { Repurchase } \\
\text { Intention } \\
\text { (Y2) }\end{array}$ & 0,319 & & 0,205 & $\begin{array}{c}\text { H2 } \\
\text { Significant }\end{array}$ \\
\hline & $\rightarrow$ & $\begin{array}{c}\text { Customer } \\
\text { Satisfaction } \\
\text { (Y1) }\end{array}$ & $\rightarrow$ & $\begin{array}{l}\text { Repurchase } \\
\text { Intention } \\
\text { (Y2) }\end{array}$ & 0,699 & & 0,735 & $\begin{array}{c}\text { H3 } \\
\text { Significant }\end{array}$ \\
\hline$e$-Trust (X1) & $\rightarrow$ & $\begin{array}{c}\text { Customer } \\
\text { Satisfaction } \\
\text { (Y1) }\end{array}$ & $\rightarrow$ & $\begin{array}{l}\text { Repurchase } \\
\text { Intention } \\
\text { (Y2) }\end{array}$ & & $\begin{array}{c}0,262 \times \\
0,699= \\
0,183\end{array}$ & 0,660 & $\begin{array}{c}\text { H4 } \\
\text { Significant }\end{array}$ \\
\hline $\begin{array}{c}\text { Post-purchase } \\
\text { Experience (X2) }\end{array}$ & $\rightarrow$ & $\begin{array}{c}\text { Customer } \\
\text { Satisfaction } \\
\text { (Y1) }\end{array}$ & $\rightarrow$ & $\begin{array}{l}\text { Repurchase } \\
\text { Intention } \\
\text { (Y2) }\end{array}$ & & $\begin{array}{c}0,534 \times \\
0,699= \\
0,373\end{array}$ & 0,692 & $\begin{array}{c}\text { H4 } \\
\text { Significant }\end{array}$ \\
\hline
\end{tabular}

The analysis of this research shows that the e-trust and post-purchase experience paths affect repurchase intention through customer satisfaction. However, when compared to the post-purchase experience path to repurchase intention through customer satisfaction, it has a total coefficient value (0.692) that is higher than the total e-trust coefficient value on repurchase intention through customer satisfaction (0.660). These results prove that in repurchase intention, consumers tend to be influenced by post-purchase experiences through customer satisfaction.

Post-purchase experience included customer services, shipping, tracking, and return provided by @jastipmlg is considered good by the customer. The results indicated that

customer repurchase interest was most influenced by the post-purchase service @jastipmlg. Jastip needs to be oriented not only to pre-purchase activities such as product posting, communication on promotion, and admin job. But also pay attention to post-purchase activities. The basic thing to note is a convenience for customers in contacting Customer Services. The availability and ability of customer services to help and solve customer problems are also important things that can be done to increase customer satisfaction which in turn increases repurchase intention.

This statement is strengthened by the results which show that the coefficient of the value obtained from the indirect effect of post-purchase experience on repurchase intention through customer satisfaction $(0,692)$ is greater than the coefficient value of direct influence, namely post-purchase experience on repurchase intention $(0,319)$.

Based on the statistical analysis of the R2 determination test appendix $\mathrm{B}$, it can be explained that the variables of e-trust, post-purchase experience, and customer satisfaction have a joint effect of 0.803 or $80.3 \%$ on repurchase intention, while the remaining $19.7 \%$ is influenced by other variables not discussed in this study.

As for the post-purchase experience variable, the indicator that best describes is Customer Service. The statement item "easy to find admin number @jastipmlg" gets the highest score of 4.09 (appendix) indicating that respondents agree that admin number @jastipmlg is easy to find. Meanwhile, for the Customer Satisfaction variable, the indicator that shows the most is in the statement item "Product quality is the same as posted by @ jastipmlg".

\section{CONCLUSION}

The research results prove that e-trust and postpurchase experience have an effect on customer satisfaction and ultimately have an impact on repurchase intention. Postpurchase experience has a direct impact on repurchase intention but has a greater impact on the indirect path, which is the post-purchase experience on repurchase intention through customer satisfaction.

Customer service is the indicator that best describes the post-purchase intention variable. The ease of obtaining an admin number is what best describes customer service which is considered by customers well. While the Customer satisfaction 


\section{CCenter for Promoting Education and Research (CPER) USAwww.cpernet.org}

variable is determined by the attributes related to the product, ability of fast response, and the ability of the admin to solve especially regarding the quality of the product received with problems. The researcher also suggests trying this research the photo at the beginning. For further research, it is advisable model for other online purchases, apart from the Instagram to conduct an in-depth study of customer service such as the platform.

\section{Reference}

Anderson, Srinivasan. (2003). E-Satisfaction and e-loyalty: a contingency framework. Psychology \& Marketing, 20(2). www.interscience.wiley.com.

Bhattacherjee, A. (2002). Individual trust in online firms: Scale development and initial test. Journal of Management Information Systems, 19(1), 211-241.

Beldad, A., De Jong, M., \& Steehouder, M. (2010). How shall I trust the faceless and the intangible? A literature review on the antecedents of online trust. Computers in Human Behavior, 26(5), 857-869.

Cao, Yingxia., Ajjan, Haya., Hong, Paul. (2018). Post-purchase shipping and customer service experiences in online shopping and their impact on customer satisfaction: An empirical study with comparison, Asia Pacific Journal of Marketing and Logistics, 30 (2), 400-416.

Chauhan, V. and Rambabu, A. (2017), “An exploratory study on consumer attitude towards buying on shopping”, International Journal \& Mangazine of Engineering, Technology, Management and Research, Vol. 4 No. 3, pp. 408-413.

Chen, S. and Chang, T. (2003), A descriptive model of online shopping process: some empirical results, International Journal of Service Industry Management, Vol. 14 No. 5, pp. 556-569.

Chiou, J.-S., L.-Y. Pan. (2009). Antecedents of internet retailing loyalty: differences between heavy versus light shoppers. Journal of Business and Psychology, 24(3): 327-339.

Chiu, C.-M., Chang, C.-C., Cheng, H.-L., \& Fang, Y.-H. (2009). Determinants of customer repurchase intention in online shopping. Online Information Review, 33(4), 761-784.

Chiu, C.-M., Hsu, M.-H., Lai, H., \& Chang, C.-M. (2012). Re-examining the influence of trust on online repeat purchase intention: The moderating role of habit and its antecedents. Decision Support Systems, 53, 835-845.

Fang, Y., Qureshi, I., Sun, H., \& McCole, P. (2014). Trust, satisfaction, and online repurchase intention: The moderating role of perceived effectiveness of e-commerce institutional mechanisms. MIS Quarterly, 38(2), 407-427.

Giovanis, A., \& Athanasopoulou, P. (2014). Gaining customer loyalty in the e-tailing marketplace: the role of e-service quality, e-satisfaction and e-trust. Int. J. Technology Marketing, Vol. 9, No. 3, pp. 288-304.

Gotama, F., Indarwati, T. A.(2019). The effect of e-trust and e-service quality to e-loyalty with e-satisfaction as the mediation variable: the study of bebas bayar application users in indonesian, Jurnal Manajemen Ide dan Kreasi, 6 (2). 145-158

Gupta, S., \& Kim, H. W. (2007). The moderating effect of transaction experience on the decision calculus in on-line repurchase. International Journal of Electronic Commerce, 12(1), 127-158.

Hapsari, A. Y., \& Saudi, M. H. (2018). The Importance of Personal Shopper's Services to Support Consumer Mobility. International Journal of Engineering \& Technology, 327-330.

Ho, C.-F. and Wu, W.-H. (1999), Antecedents of customer satisfaction on the internet: an empirical study of online shopping", IEEE Proceedings of the 32nd Annual Hawaii International Conference on Systems Sciences (HICSS-32), p. 9, available at: http://ieeexplore.ieee.org/xpls/ abs_all.jsp?arnumber=647447.

Hsu, M., Chang, C.,Chu, K., Lee, Y. (2014). Determinants of repurchase intention in online group-buying: The perspectives of DeLone \& McLean IS success model and trust. J Computers in Human Behavior, 36, 234-245.

Hu, T., Kettinger, W. J., \& Poston, R. S. (2015). The effect of online social value on satisfaction and continued use of social media. European Journal of Information Systems, 24(4), 391-410.

Kim, H. W., Xu, Y., \& Koh, J. (2004). A comparison of online trust building factors between potential customers and repeat customers. Journal ofthe Association for Information Systems, 5(10), 392-420.

Kim, J. B. (2012). An empirical study on consumer first purchase intention in online institutional mechanisms. MIS Quarterly, $38(2), 407-427$. 


\section{CCenter for Promoting Education and Research (CPER) USAwww.cpernet.org}

Kim, D. J. (2014). A study of the multilevel and dynamic nature of trust in e-commerce, 39-50.

Koller, M. (1988). Risk as a determinant of trust. Basic and Applied Social Psychology, 9(4), 265-276.

Kotler, P. (2006), Marketing Management, $1^{\text {st }}$ Edition, PT. Indeks Kelompok Gramedia, Indonesia

Kumar, A., Anjaly, B. (2017). How to measure post-purchase customer experience in online retailing? A scale development study, International Journal of Retail \& Distribution Management, 45 (12).1277-1297

Lin, H. H., \& Wang, Y. S. (2006). An examination of the determinants of customer loyalty in mobile commerce contexts. Information \& Management, 43, 271-282.

Lee, C. H., Eze, U. C., \& Ndubisi, N. O. (2011). Analyzing key determinants of online repurchase intention. Asia Pacific Journal of Marketing and Logistics, 23(2), 200-221

Marcos, M., Suarez, S., Marcos, M., Fernandez-miranda, S., Marcos, M. P., \& F, A. (2017). The challenge of integrating Industry in the degree of Mechanical Engineering. Procedia Manufacturing, 1229-1236.

McKinney, V., Yoon, K., \& Zahedi, F. (2002). The measurement of Web-customer satisfaction: An expectation and disconfirmation approach. Information Systems Research, 13(3), 296-315

Muslicha, I. S., \& Irwansyah (2020). Instagram, the Jastip phenomenon in Indonesia. Journal Communication Spectrum: Capturing New Perspectives in Communication, 9 (2), 143-157.

Pavlou, P. A., \& Fygenson, M. (2006). Understanding and predicting electronic commerce adoption: An extension of the theory of planned behavior. MIS quarterly, 30(1), 115-143.

Park, I., Cho, J. and Rao, H.R. (2012), The effect of pre-and post-service performance on consumer evaluation of online retailers, Decision Support Systems, 55 (2) pp. 415-426

Park, C. and Kim, Y. (2003), "Identifying key factors affecting consumer purchase behavior in an online shopping context", International Journal of Retail \& Distribution Management, Vol. 31 No. 1, pp. 16-29, doi: $10.1108 / 09590550310457818$.

Pee, L. G., Jiang, J., Klein, G. (2018). Signaling effect of website usability on repurchase intention. International Journal of Information Management. (39), 228-241

Pleessis, L. D. (2010). Customer relationship management and its influence on customer loyalty at Liberty Life in South Africa. University of Johannesberg, 2010

Qureshi, I., Fang, Y., Ramsey, E., McCole, P., Ibbotson, P., \& Compeau, D. (2009). Understanding online customer repurchasing intention and the mediating role of trust - An empirical investigation in two developed countries. European Journal of Information Systems, 18(3), 205-222

Said, A. A. (2019, August 22). Riset: Rerata Konsumen Indonesia Belanja $R p \quad 3,9$ Juta di $E$ commerce. Retrieved from katadata.co.id: https://katadata.co.id/berita/2019/08/22/riset-rerata-konsumen-indonesiabelanja-rp-39-juta-di-e-commerce. diakses pada 28 April 2020

Samuel, Hatane dan Foedjiawati. (2005). The effect of customer satisfaction on brand loyalty (Study on The Prime Steak \& Ribs Surabaya). Journal of Management \& Entrepreneurship. 7.

Shin, J. I., Chung, K. H., Oh, J. S., \& Lee, C. W. (2013). The effect of site quality on Repurchase Intention in Internet shopping through mediating variables: The case of university students in South Korea. International Journal of Information Management, 453-463.

Shiau, W. L., \& Luo, M. M. L. (2012). Factors affecting online group buying intention and satisfaction: A social exchange theory perspective. Computers in Human Behavior, 28(6), 2431-2444.

Susanto, S. A. (2018), The effect of e-satisfaction \& e-trust of hotel consumers on online repurchase intention in Traveloka. Jurnal Hospitality dan Manajemen Jasa, 6 (1). 54-65

Spagnoletti, A. (2014), "Shipping and delivery: what customers expect from online retailers", May 13, available at: http://ventureburn.com/2014/05/shipping-and-delivery-what-customers-expect- from-online-retailers/, diakses pada 30 April 2020

Tsai, H.-T., \& Huang, H.-C. (2007). Determinants of e-repurchase intentions: An inte- grative model of quadruple retention drivers. Information \& Management, 44(3), 231-239

Tsiotsou, R., 2006. The role of perceived product quality and overall satisfaction on purchase intentions. International Journal of Consumer Studies., 30: 207-217 


\section{CCenter for Promoting Education and Research (CPER) USAwww.cpernet.org}

Yen, C. H., \& Lu, H. P. (2008). Factors influencing online auction repurchase intention. Internet Research, 18(1), 7-25.

Verhagen, T., Meents, S., \& Tan, Y. H. (2006). Perceived risk and trust associated with purchasing at electronic marketplaces. European Journal of Information Systems, 15, 542-555.

Venkatesh, V., Thong, J. L., Chan, F. Y., Hu, P. J., \& Brown, S. A. (2011). Extending the two-stage information systems continuance model: Incorporating UTAUT predictors and the role of context. Information Systems Journal, 21(6), 527555.

Wen, C., Prybutok, V. R., \& Xu, C. (2011). An integrated model for customer online repurchase intention. Journal of Computer Information Systems, Fall, 14-23.

Zhou, T., Lu, Y., \& Wang, B. (2009). The relative importance of website design quality and service quality in determining consumers' online repurchase behavior. Information Systems Management, 26(4), 327-337.

Zoltners, A., Sinha, P. and Lorimer, S. (2004), Sales Force Design for Strategic Advantage, Springer, New York, NY

\section{APPENDIX A Exploratory factor analysis results}

\begin{tabular}{|c|c|c|c|c|c|c|c|c|c|c|c|c|}
\hline \multirow{3}{*}{ No } & \multirow{3}{*}{ Instrument } & \multicolumn{10}{|c|}{ Score } & \multirow{3}{*}{ Average } \\
\hline & & \multicolumn{2}{|c|}{$\mathrm{SA}(5)$} & \multicolumn{2}{|c|}{ A (4) } & \multicolumn{2}{|c|}{$\mathrm{U}(3)$} & \multicolumn{2}{|c|}{$\mathrm{D}(2)$} & \multicolumn{2}{|c|}{$\mathrm{SD}(1)$} & \\
\hline & & $\mathrm{F}$ & $\%$ & $\mathrm{~F}$ & $\%$ & $\mathrm{~F}$ & $\%$ & $\mathrm{~F}$ & $\%$ & $\mathrm{~F}$ & $\%$ & \\
\hline 1 & The @ jastipmlg account posted photos of real products as I received them (X1.1.1) & 28 & 28 & 52 & 52 & 20 & 20 & 0 & 0 & 0 & 0 & 4,08 \\
\hline 2 & The @ jastipmlg account can be relied upon to find fashion products (X1.1.2) & 24 & 24 & 48 & 48 & 27 & 27 & 1 & 1 & 0 & 0 & 3,95 \\
\hline 3 & I visited @ jastipmlg to see the shop promo I was looking for (X1.1.3) & 24 & 24 & 49 & 49 & 20 & 20 & 6 & 6 & 1 & 1 & 3,89 \\
\hline \multicolumn{12}{|c|}{ Avg Score trust in web (X1.1) } & 3,97 \\
\hline 4 & $\begin{array}{l}\text { I rely on admin @ jastipmlg to get information on the product I want to buy } \\
\text { (X1.2.1) }\end{array}$ & 23 & 23 & 46 & 46 & 30 & 30 & 1 & 1 & 0 & 0 & 3,91 \\
\hline 5 & $\begin{array}{l}\text { Admin @ jastipmlg keeps promises according to commitments to customers } \\
\text { (X1.2.2) }\end{array}$ & 16 & 16 & 46 & 46 & 32 & 32 & 6 & 6 & 0 & 0 & 3,72 \\
\hline 6 & Admin@jastipmlg still takes care of customers (X1.2.3) & 22 & 22 & 48 & 48 & 26 & 26 & 4 & 4 & 0 & 0 & 3,88 \\
\hline \multicolumn{12}{|c|}{ Avg score trust in seller (X1.2) } & 3,84 \\
\hline \multicolumn{12}{|c|}{ Avg score $e$-trust (X1) } & 3,90 \\
\hline \multirow{3}{*}{ No } & \multirow{3}{*}{ Instrument } & \multicolumn{10}{|c|}{ Score } & \multirow{3}{*}{ Average } \\
\hline & & \multicolumn{2}{|c|}{ SA (5) } & \multicolumn{2}{|c|}{$\mathrm{A}(4)$} & \multicolumn{2}{|c|}{$\mathrm{U}(3)$} & \multicolumn{2}{|c|}{$\mathrm{D}(2)$} & \multicolumn{2}{|c|}{$\mathrm{SD}(1)$} & \\
\hline & & $\mathrm{F}$ & $\%$ & $\mathrm{~F}$ & $\%$ & $\mathrm{~F}$ & $\%$ & $\mathrm{~F}$ & $\%$ & $\mathrm{~F}$ & $\%$ & \\
\hline 1 & Easily find @ jastipmlg admin number to ask about jastip services (X2.1.1) & 26 & 26 & 57 & 57 & 17 & 17 & 0 & 0 & 0 & 0 & 4,09 \\
\hline 2 & Admin @ jastipmlg is willing to help customers $(\mathrm{X} 2.1 .2)$ & 21 & 21 & 54 & 54 & 21 & 21 & 4 & 0 & 0 & 0 & 3,92 \\
\hline 3 & Admin @jastipmlg helps in solving customer problems (X2.1.3) & 21 & 21 & 46 & 46 & 30 & 30 & 3 & 3 & 0 & 0 & 3,85 \\
\hline \multicolumn{12}{|c|}{ Avg score Customer Service (X2.1) } & 3,95 \\
\hline 4 & @ jastipmlg deliver products according to the agreed time (X2.2.1) & 24 & 24 & 46 & 46 & 29 & 29 & 1 & 1 & 0 & 0 & 3,93 \\
\hline 5 & I often receive free / discounted shipping (X2.2.2) & 13 & 13 & 34 & 34 & 39 & 39 & 13 & 13 & 1 & 1 & 3.45 \\
\hline 6 & @ jastipmlg gives me flexibility to choose delivery date (X2.2.3) & 18 & 18 & 45 & 45 & 34 & 34 & 3 & 3 & 0 & 0 & 3,78 \\
\hline \multicolumn{12}{|c|}{ Avg score Shipping (X2.2) } & 3,86 \\
\hline 1 & @ jastipmlg notified me that the item was delivered (X2.3.1) & 21 & 21 & 51 & 51 & 28 & 28 & 0 & 0 & 0 & 0 & 3.93 \\
\hline 2 & @ jastipmlg help me to do tracking during delivery (X2.3.2) & 19 & 19 & 42 & 42 & 36 & 36 & 3 & 3 & 0 & 0 & 3,77 \\
\hline 3 & I can track my shipment with my mobile device (X2.3.3) & 25 & 25 & 40 & 40 & 33 & 33 & 2 & 2 & 0 & 0 & 3,86 \\
\hline \multicolumn{12}{|c|}{ Avg score Tracking (X2.3) } & 3,82 \\
\hline 4 & Easy for me to make returns / exchanges (X1.4.1) & 17 & 17 & 40 & 40 & 37 & 37 & 6 & 6 & 0 & 0 & 3,68 \\
\hline 5 & @ jastipmlg has a clear return policy (X1.4.2) & 13 & 13 & 31 & 31 & 47 & 47 & 9 & 9 & 0 & 0 & 3,48 \\
\hline \multicolumn{12}{|c|}{ Avg score Return (X2.4) } & 3,58 \\
\hline \multicolumn{12}{|c|}{ Avg score Post-purchase Experience (X2) } & 3,79 \\
\hline
\end{tabular}




\section{(C) Center for Promoting Education and Research (CPER) USAwww.cpernet.org}

\begin{tabular}{|c|c|c|c|c|c|c|c|c|c|c|c|c|}
\hline \multirow{3}{*}{ `No } & \multirow{3}{*}{ Instrument } & \multicolumn{10}{|c|}{ Score } & \multirow{3}{*}{ Average } \\
\hline & & \multicolumn{2}{|c|}{ SA (5) } & \multicolumn{2}{|c|}{ A (4) } & \multicolumn{2}{|c|}{$\mathrm{U}(3)$} & \multicolumn{2}{|c|}{$\mathrm{D}(2)$} & \multicolumn{2}{|c|}{$\mathrm{SD}(1)$} & \\
\hline & & $\mathrm{F}$ & $\%$ & $\mathrm{~F}$ & $\%$ & $\mathrm{~F}$ & $\%$ & $\mathrm{~F}$ & $\%$ & $\mathrm{~F}$ & $\%$ & \\
\hline 1 & Same product quality as posted by @ jastipmlg (Y1.1.1) & 30 & 30 & 47 & 47 & 22 & 22 & 1 & 1 & 0 & 0 & 4,06 \\
\hline 2 & Products from @ jastipmlg are neatly packaged as expected (Y1.1.2) & 23 & 23 & 49 & 49 & 26 & 26 & 2 & 2 & 0 & 0 & 3,93 \\
\hline \multicolumn{12}{|c|}{ Avg score Attributes related to the product (Y1.1) } & 4,00 \\
\hline 3 & The services provided by @ jastipmlg are very good (Y1.2.1) & 26 & 26 & 51 & 51 & 23 & 23 & 0 & 0 & 0 & 0 & 4,03 \\
\hline 4 & $\begin{array}{l}\text { I get a bonus or discount from @ jastipmlg outside of store promos } \\
\text { (Y1.2.2) }\end{array}$ & 24 & 24 & 31 & 31 & 38 & 38 & 6 & 6 & 1 & 1 & 3,71 \\
\hline \multicolumn{12}{|c|}{ Avg score Attributes related to service (Y1.2) } & 3,87 \\
\hline 7 & $\begin{array}{l}\text { I received a payment confirmation for the transaction I made with } \\
\text { @ jastipmlg (Y1.3.1) }\end{array}$ & 28 & 28 & 42 & 42 & 28 & 28 & 2 & 2 & 0 & 0 & 3,96 \\
\hline 8 & Ease of transactions @ jastipmlg with various payment methods (Y1.3.2) & 25 & 25 & 41 & 41 & 33 & 33 & 1 & 1 & 0 & 0 & 3,90 \\
\hline \multicolumn{12}{|c|}{ Avg score Attributes related to purchase (Y1.3) } & 3,93 \\
\hline \multicolumn{12}{|c|}{ Avg score Customer Satisfaction (Y1) } & 3,93 \\
\hline
\end{tabular}

\begin{tabular}{|c|c|c|c|c|c|c|c|c|c|c|c|c|}
\hline \multirow{3}{*}{ `No } & \multirow{3}{*}{ Instrument } & \multicolumn{10}{|c|}{ Score } & \multirow{3}{*}{ Average } \\
\hline & & \multicolumn{2}{|c|}{ SA (5) } & \multicolumn{2}{|c|}{ A (4) } & \multicolumn{2}{|c|}{$\mathrm{U}(3)$} & \multicolumn{2}{|c|}{$\mathrm{D}(2)$} & \multicolumn{2}{|c|}{ SD (1) } & \\
\hline & & $\mathrm{F}$ & $\%$ & $\mathrm{~F}$ & $\%$ & $\mathrm{~F}$ & $\%$ & $\mathrm{~F}$ & $\%$ & $\mathrm{~F}$ & $\%$ & \\
\hline 1 & I want to reuse personal shopper via @ jastipmlg (Y2.1.1) & 38 & 38 & 34 & 34 & 27 & 27 & 1 & 1 & 0 & 0 & 4,09 \\
\hline \multicolumn{12}{|c|}{ Avg score Interest (Y2.1) } & 4,09 \\
\hline 3 & I visited @ jastipmlg to make purchases of fashion products (Y2.2.1) & 30 & 30 & 41 & 41 & 27 & 27 & 2 & 2 & 0 & 0 & 3,99 \\
\hline 4 & I plan to reuse personal shoppers via @ jastipmlg in the future (Y2.2.2) & 30 & 30 & 40 & 40 & 29 & 29 & 1 & 1 & 0 & 0 & 3,99 \\
\hline \multicolumn{12}{|c|}{ Avg score Revisited in the future (Y2.2) } & 3,99 \\
\hline 7 & I recommend @ jastipmlg to make purchases of fashion products (Y2.3.1) & 31 & 31 & 43 & 43 & 21 & 21 & 5 & 5 & 0 & 0 & 4,00 \\
\hline 8 & I will leave a good review of @ jastipmlg (Y2.3.2) & 37 & 37 & 41 & 41 & 18 & 18 & 4 & 4 & 0 & 0 & 4,11 \\
\hline \multicolumn{12}{|c|}{ Avg score Recommendation (Y2.3) } & 4,06 \\
\hline \multicolumn{12}{|c|}{ Avg score Repurchase Intention (Y2) } & 4,03 \\
\hline
\end{tabular}

\section{APPENDIX B R SQUARE}

\begin{tabular}{|l|l|}
\hline Correlation Variable & r Square $\left(\mathrm{r}^{2}\right)$ \\
\hline E-trust \& Post-purchase experience $\rightarrow$ Customer satisfaction & 0.737 \\
\hline E-trust \& Post-purchase experience $\rightarrow$ Repurchase intention & 0.731 \\
\hline Customer satisfaction $\rightarrow$ Repurchase intention & 0.699 \\
\hline E-trust \& Customer satisfaction $\rightarrow$ Repurchase intention & 0.772 \\
\hline $\begin{array}{l}\text { Post-purchase experience \& Customer satisfaction } \rightarrow \\
\text { Repurchase intention }\end{array}$ & 0.728 \\
\hline $\begin{array}{l}\text { E-trust, post-purchase experience \& Customer satisfaction } \\
\rightarrow \text { Repurchase intention }\end{array}$ & 0,803 \\
\hline
\end{tabular}

